Int. J. Dev. Biol. 61: 5-15 (2017)

doi: $10.1387 / \mathrm{ijdb} .160408 \mathrm{gv}$

\title{
Trunk neural crest cells: formation, migration and beyond
}

\author{
GUILLERMO A. VEGA-LOPEZ ${ }^{\#, 1}$, SANTIAGO CERRIZUELA ${ }^{\#, 1}$ and MANUEL J. AYBAR ${ }^{*, 1,2,}$ \\ ${ }^{1}$ Instituto Superior de Investigaciones Biológicas (INSIBIO, CONICET-UNT) and ${ }^{2}$ Instituto de Biologia "Dr. Francisco \\ D. Barbieri", Facultad de Bioquímica, Química y Farmacia, Universidad Nacional de Tucumán, Argentina
}

\begin{abstract}
Neural crest cells (NCCs) are a multipotent, migratory cell population that generates an astonishingly diverse array of cell types during vertebrate development. The trunk neural crest has long been considered of particular significance. First, it has been held that the trunk neural crest has a morphogenetic role, acting to coordinate the development of the peripheral nervous system, secretory cells of the endocrine system and pigment cells of the skin. Second, the trunk neural crest additionally has skeletal potential. However, it has been demonstrated that a key role of the trunk neural crest streams is to organize the innervation of the intestine. Although trunk NCCs have a limited capacity for self-renewal, sometimes they become neural-crest-derived tumor cells and reveal the fact that that NCCs and tumor cells share the same molecular machinery. In this review we describe the routes taken by trunk NCCs and consider the signals and cues that pattern these trajectories. We also discuss recent advances in the characterization of the properties of trunk NCCs for various model organisms in order to highlight common themes. Finally, looking to the future, we discuss the need to translate the wealth of data from animal studies to the clinical area in order to develop treatments for neural crest-related human diseases.
\end{abstract}

KEY WORDS: trunk neural crest, migration, neurogenesis, enteric nervous system, neurocristopathies

\section{Introduction}

One characteristic that separates vertebrates from other metazoans is the cell population called the neural crest (NC). This embryonic tissue is composed of cells arising at the border between the non-neural ectoderm and neural ectoderm. This population is also characterized by having multipotent and stem-cell-like properties. After being induced, neural crest cells (NCCs) undergo a process known as epithelial-to-mesenchymal transition (EMT) and migrate to distinct locations within the embryo to generate a wide diversity of cell derivatives (Duband et al., 1995, Kerosuo and Bronner-Fraser, 2012).

With the exception of the most anterior part of the embryo, NCCs are generated along the entire length of the anterior-posterior (AP) axis. Derivative tissues arising from the NC originate from four different segments of the AP axis: cranial, cardiac, vagal and trunk NC. The cranial NC participates in the formation of the cartilage and bone of the head, nerve ganglia, smooth muscle, connective tissue and pigment cells. The cardiac NC participates in heart development, while the vagal NC contributes to the enteric ganglia of the gut. Finally, the trunk NC will give rise to neurons and glia of the peripheral nervous system (PNS), secretory cells of the endocrine system and pigment cells of the skin (Etchevers et al., 2001).

The understanding of the development of the NC has important medical implications since a variety of birth defects arise from abnormal processes in the induction, specification and migration of NCCs and affect NC derivatives postnatally. These abnormalities, called neurocristopathies, are one of the most common birth defects in live-born infants, including defects in the cardiac outflow tract, craniofacial malformations, familial dysautonomia, and a range of syndromes including Tracher-Collins, Waardenburg, DiGeorge and Charge syndromes (Etchevers et al., 2006). It is thus of crucial importance to develop experimental approaches that will allow the suitable dissection of the cellular and genetic features of human NCCs.

\footnotetext{
Abbreviations used in this paper: AP, antero-posterior; BMP, bone morphogenetic protein; DRG, dorsal root ganglia; ECM, extracellular matrix; EMT, epithelialto-mesenchymal transition; ENS, enteric nervous system; Eph, ephrin receptor; FGF, fibroblast growth factor; NC, neural crest; NCGs, neural crest cells; NCSCs, neural crest stem cells; NT, neural tube; RA, retinoic acid; tNC, trunk neural crest; tNCGs, trunk neural crest cells; Sem, semaphorin; Shh, Sonic hedgehog.
}

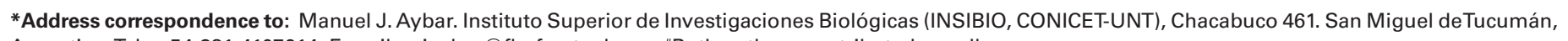
Argentina.Tel.: +54-381-4107214. E-mail: mjaybar@fbqf.unt.edu.ar - "Both authors contributed equally

(iD) http://orcid.org/0000-0002-7187-6435

Supplementary Material for this paper is available at: http://dx.doi.org/10.1387/ijdb.160408gv

Submitted: 4 November 2016; Accepted: 12 December 2016.

ISSN: Online 1696-3547, Print 0214-6282

() 2017 UPV/EHU Press

Printed in Spain 
The stem and pluripotent properties of NCCs, combined with an exceptional diversity of cell type and cell differentiation, have made NCCs an interesting target in regenerative medicine. This is sustained by the fact that NC stem cells (NCSCs) are retained postnatally in the skin, peripheral nerves, gut, heart and bone marrow (Dyachuk et al., 2014).

One of the most remarkable properties of the NC is its striking similitude to malignant cancer cells. Malignant tumor cells mimic many behavioral and morphological aspects of NC development. Loss of apicobasal polarity, changes in adhesion, degradation of the ECM, cell proliferation, migration and pluripotency are mechanisms shared by both cell types as they go to their final destinations and differentiate (Kerosuo and Bronner-Fraser, 2012, Maguire et al., 2015).

During the past two decades numerous investigations have documented the induction, specification, delamination and migration of trunk NCCs (tNCCs). Despite this fact, more work is needed to provide straightforward evidence concerning the application of tNCCs in the regeneration of specific cell types, in the repair of damaged tissue and in the potential therapies against various types of cancer.

In this review we will focus on the formation of the trunk NC and its molecular events, and the delamination and migration pathways. We will also address the difference in molecular signature and behavior of the tNCCs between different species, and the differentiation into diverse derivatives. Finally, we will outline several applications of $\mathrm{tNCC}$ in regenerative medicine and cancer therapy.

\section{Trunk neural crest - overview}

As mentioned above, the NC gives rise to multiple organs and tissues of the adult organism. The two major population of the NC are the cranial NC and the trunk NC (tNC). Cranial NCCs migrate



Fig. 1. Model of neural crest (NC) initial induction. Dorsolateral view of a schematic model embryo. A ventro-medial gradient of BMPs (red) is established in the ectoderm, specifying the neural plate border as neural fold (NF, brown) at a threshold concentration. Posteriorizing signals (green) which correspond to the activities of Wnts, FGFs and RA transform the lateral and posterior part of the neural plate border into prospective NC cells (blue). These signals are also generated in a gradient-like manner, with higher levels in the posterior part of the ectoderm and lower levels in the anterior region. These lower anterior levels are also kept low by antiposteriorizing molecules such as Dickkopf and Cerberus (Wnts antagonists, $D k k$ and Cer), in pink, produced in the anterior region of the embryo. A, anterior; P, posterior; $D$, dorsal; $V$, ventral. Modified figure from Niehrs (2004), redrawn and upgraded. into three streams: adjacent to the neural tube from the diencephalon to rhombomere 2(r2), adjacent to $\mathrm{r} 4$, and adjacent to the postotic region from r6 to $r 8$. NCCs from $r 3$ and $r 5$ migrate rostrally and caudally to join adjacent streams (Kulesa et al., 2010, Kuriyama and Mayor, 2008, Lumsden and Guthrie, 1991). The mechanism and processes involved in cranial NC induction, delamination and migration have been extensively reviewed elsewhere (Gong, 2014, Minoux and Rijli, 2010), and other references).

Trunk NCCs arise from the caudal region of the embryo and migrate along three different pathways: a dorsolateral pathway between the ectoderm and the somites, a ventro-lateral pathway in which cells migrate between and through the somites, and a ventro-medial pathway between the neural tube (NT) and the posterior sclerotome (Gammill and Roffers-Agarwal, 2010, Krispin et al., 2010, McLennan et al., 2015, Richardson et al., 2016). Therefore, the pathways taken by the tNCCs and their final destinations are critically influenced by the surrounding structures, particularly somites and signaling molecules present in this tissue and those from surrounding ones.

The physical structure of the somite provides different kinds of attractive and inhibitory cues that modulate NCCs migration and differentiation. For example, somites are crucial as physical impediments, as a substrate for migration, and as a source of signals. Another case of influence on NC migration comes from the notochord. It repels migratory NCCs, causing them to gather at the dorsal aorta where they differentiate into sympathetic glia (Gammill and Roffers-Agarwal, 2010).

\section{Induction and multipotency of tNCCs: signals that guide their development}

NC progenitors are induced at the neural plate border as a consequence of the integration of complex signaling events involving the BMP, Wnt, RA and FGF pathways (Fig. 1) (Aybar and Mayor, 2002). The signaling molecules and transcription factors that are required for NC specification, maintenance of the specification, migration and differentiation can be explained as a gene regulatory network that defines their individual and combinatorial roles in transcriptional regulation (Betancur et al., 2010a). The transcription factors involved in such processes can be grouped according to their biological role into neural plate border specifiers, NC specifiers, NC/EMT migration factors, and factors that direct the differentiation of NCCs into specific derivative cell types (Taylor and LaBonne, 2007). More specifically, it is known that in the tNC the transcription factors sox 9 , foxd 3 and slug are sufficient to specify NCCs and induce EMT (Cheung et al., 2005, Liu et al., 2013, Nitzan et al., 2013). It is important to note that perhaps due to current experimental limitations or to the intrinsic complexities of each model organism analyzed, it has not been possible at present to find inductive mechanisms unique to each particular region of the NC. However, it has been reported that some differences do exist in the development of cranial versus tNCC (i.e. at the onset of gene expression), although similar mechanisms are implicated in NC formation (Osorio et al., 2009).

With respect to the NC potency and migration suggested, it has been proposed that there could be three possible scenarios relating to the properties of the pool of premigratory NCCs. In one case the NC may be assumed to be a homogeneous population of totipotent cells, each with a remarkable developmental poten- 
tial. Following migration, the cells could differentiate according to instructive cues from their surroundings, either during migration or at their final destination. In the second case the potentiality of each cell could be characteristic of its NC population. In this scenario, the NC would be composed of a heterogeneous mixture of predetermined cells, each destined to become a particular cell type. A third possibility is that the NC represents a combination of multipotent and predetermined cells (Fig. 2, green and yellow cells) (McKinney et al., 2013). Over the past 25 years since the establishment of these three putative models, numerous investigations have been performed to assess this basic question about the potentiality of NCCs. One group of investigations concluded that NCCs were multipotent in vivo (McKinney et al., 2013) and in vitro (Dupin and Sommer, 2012). However, other publications reported that the NC was formed by a heterogeneous population of restricted progenitor cells (Krispin et al., 2010). Recently, it has been shown that the vast majority of NCCs, at least in the case of the murine embryo, are multipotent prior to and during migration (Baggiolini et al., 2015, Bronner, 2015).

\section{EMT and delamination of trunk NCCs}

After NCCs have been induced and have become pluripotent to differentiate into various types of derivatives they undergo EMT (epithelial-to-mesenchymal transition). In this transition they delaminate from the NT or from the neuroepithelium and convert from epithelium-like cells to mesenchyme-like cells, which are capable of migrating along the entire embryo (Kerosuo and Bronner-Fraser,
2012, Nieto, 2009).

The EMT is thought to be promoted by the activation of BMP and a simultaneous upregulation of the Wnt signaling pathway (Ahlstrom and Erickson, 2009). Before and after delaminating from the NT and during their migration there is an extensive and complex network of up- and down-regulation of cell adhesion molecules such as cadherins, connexins, occludins and integrins (Taneyhill, 2008). In chick embryos, neural fold cells express cadherin-6B (Nakagawa and Takeichi, 1995). An important factor in the start of migration of $\mathrm{NC}$ cells is the downregulation of $\mathrm{N}$-cadherin. This requires the coordinated action of BMP signaling and the proteolytic action of the transmembrane protein ADAM10, which cleaves the extracellular domain of $\mathrm{N}$-cadherin (Osorio et al., 2009, Shoval et al., 2007). In the case of the Xenopus embryo, cadherin-11 has an important function, and is expressed in the anterior neural folds and in migrating NCCs (Vallin et al., 1998). In the zebrafish embryo, the Sonic Hedgehog (Shh) receptor and cell adhesion regulator, Cdon, has been shown to play a key role in the directed migration of tNCCs, by regulating $\mathrm{N}$-cadherin localization (Powell et al., 2015). Thus the process of EMT in tNCC is more complex than previously thought, involving several signal molecules and secreted factors, with the addition of cell adhesion molecules, all of which are involved in a complex regulatory network.

\section{Regional differences between cranial and tNCCs}

The molecular mechanisms governing the induction and specification of NCCs vary in accordance to the axial level. An early
Fig. 2. Trunk neural crest cell migration. In the trunk of the embryo, neural crest cells (NCCS) migrate in the following ways: (1) a minority of NCCs move ventrally through the dorsalanterior sclerotome la permissive but not preferred substrate) by traveling laterally on myotomal basal lamina to form: a) dorsal root ganglia, b) sympathetic ganglia and c) adrenal medulla; (2) between the neural tube and somites to give rise to the sympathetic and sensory ganglia; (3) ventrally between the somites along intersomitic vessels. (4) After ventral migration is complete, NCCs leave the staging area and enter the dorso-lateral path between the ectoderm and the anterior sclerotome. (5) They also migrate dorso-laterally under the ectoderm and over the dermomyotome to give rise to the pigment cells of the skin (melanoblasts or feathers). Differences in

"species-specific" cell surface molecules dictate the various cell migration behaviors. A feature-rich model of the trunk NC migratory streams of this figure is shown in an interactive 3D-pdf in Supplementary Fig. 1. Adapted from Dr. Brian E. Staveley, Memorial University of Newfoundland, redrawn and upgraded. a, dorsal aorta; a-scl, anterior sclerotome; dm, dermomyotome; ect, ectoderm; nc, notochord; nt, neural tube; p-scl, posterior sclerotome; v, vein. 
difference between cranial and trunk NCCs is the expression of a distinctive gene marker. In the case of cranial NCCs, the marker that differentiates them from the trunk NC is the ets-1 gene (Theveneau et al., 2007), whereas a bona fide tNC marker has not yet been found. The kinesin eg5, another early gene with expression in the pre-delamination trunk stage, and ednrb2-c during migration, could be good candidates as well (Fernandez et al., 2014, Kawasaki-Nishihara et al., 2011, Square et al., 2016).

Another regional difference is the distinct regulation of NC specifier genes. For example, the NC specifier gene, namely foxd3, has an enhancer region that receives different inputs with respect to the axial level. The cranial NC enhancer requires an Ets-1 input, whereas the trunkenhancer requires Zic1. Thus there are differential inputs mediating foxd3 expression in cranial NC versus trunk NC (Simoes-Costa et al., 2012). Another case of differential regulation of protein expression is that of sox10. In cranial NCCs the sox10 gene expression is driven by the sox10E2 enhancer, while in trunk NC the enhancer is Sox10E1 (Betancur et al., 2010b).

Going into the delamination phase of NC development, there are also differences in the regulation of this process between cranial and trunk NCCs. In mouse and chicken cranial NCCs, the transcription factor Sip1 is essential for the delamination of the cells (Rogers et al., 2013). On the other hand, in tNCCs, besides the participation of the Sip1 protein, the transcription factor $\delta E F 1$ is also required for NCC delamination (Yasumi et al., 2016).

Patterning of NC cells into distinct streams and their precise targeting to specific tissues are controlled by a plethora of negative and positive guidance cues than can work by two different models, follow-the-leader or cell-cell-contact. In the follow-the-leader model, leader and follower identities are acquired before the start of migration and remain fixed after that (Kelsh et al., 2009, Kuo and Erickson, 2010, McLennan et al., 2012, Wynn et al., 2013). In the cell-cell contact, the cell needs a co-attraction and contact inhibition of locomotion, and identities could be acquired after the onset of migration (Broders-Bondon et al., 2016, Szabo and Mayor, 2016). In chick and zebrafish it has been shown that whereas cranial NCCs do not require leader cells for their migration and all the cells present similar migratory capacities, tNCCs require leader cells to direct movement and cell-cell contact. It has also been shown that the leader and follower identities are acquired before the initiation of the migration and remain fixed after that (Richardson et al., 2016). This could also be an intrinsic difference between cranial and tNC that lies in the migration mechanism.

\section{The tNCC migration routes}

Right after delamination, the NCCs of the trunk region of the embryo start to migrate along three different routes (Fig. 2). The first NCCs that delaminate and migrate start doing so in a ventral way around the epithelial somites, mostly along blood vessels in the intersomitic space. They also migrate between the somites and the NT. After the somites have matured and dissociated into dermomyotome and sclerotome, a second set of NCCs begins to invade the sclerotome and migrate ventrolaterally through different parts of the somite, depending upon the particular species of organism (Serbedzija et al., 1990). A third wave of NCCs migrate along a dorsolateral pathway between the epidermal ectoderm and the dermomyotome (Erickson et al., 1992). The possible mechanisms guiding or controlling the migration of each cellular group are discussed below. An increasing amount of evidence suggests that the transition from ventral to dorsal pathway preference is NCCs autonomous and not due to changes in the environment (Kuo and Erickson, 2011, Simkin et al., 2013).

\section{Species-specific differences in tNC migration pathways}

Developmental biology has taught us that the development of very different species is strikingly similar. Nonetheless, regarding the timing and trajectories of migration of trunk NCCs, there are a few differences between the four major model organisms, i.e. Xenopus laevis, Mus musculus, Gallus gallus and Danio rerio.

In mouse and chick embryos, tNCCs start migrating ventrally in a non-segmented way between the NT and the somites, favoring the intersomitic space. After the maturation of the somite, NC cells pass through the anterior half of the sclerotome and along the basement membrane of the dermomyotome (Hall, 2008). As mentioned above, the third pathway undertaken by tNCCs is the dorsolateral one. In mouse embryos both routes are invaded simultaneously, while in chick this third wave invades the dorsolateral pathway with a 48-hour delay (Kuo and Erickson, 2010).

In zebrafish, trunk NCCs start migrating along a medial pathway in-between the somites and the NT. These NCCs align to and are affected by slow muscle cells in the middle part of the somite (Honjo and Eisen, 2005). After $4 \mathrm{hs}$ of the start of migration through the medial pathway, NCCs commence migrating on the dorsolateral pathway between the epidermis and the somite (Raible et al., 1992). In contrast to other species, zebrafish melanocytes precursors are composed of NCCs arriving from the dorsal pathway as well as from the medial pathway (Kelsh et al., 2009). In Xenopus, as opposed to chick and mouse, trunk NCCs pass through the caudal region of the somite during their ventromedial migration. In addition, few NCCs migrate along the lateral pathway under the ectoderm (Collazo et al., 1993).

The migration of the NC has been studied not only in these major vertebrate organisms, but also in more basal vertebrates such as the lamprey and hagfish. In lamprey we can distinguish three major NC populations: the trigeminal crest (TC), the hyoid crest ( $\mathrm{HC}$ ) and the branchial crest (BC). Although the head-trunk differentiation in the lamprey is not yet completed and there is no clear differentiation in trunk and cranial NC in this species, BC cells can be considered similar to tNC since the branchial region is expanded caudally. In regard to their migration, BC cells are found superficially to the arch mesoderm, indicating that these cells migrate along the dorsolateral pathway (Mukendi et al., 2016). All the results mentioned above stress the fact that migration of NCCs varies between different species and among various phyla.

\section{Light traffic control during tNCC migration}

tNCCs have the potential to differentiate into a multitude of cell derivatives including neurons and glia of the sensory and autonomic nervous system. Such cell derivatives also include the neurons and glia of the dorsal root (DRG) and sympathetic ganglia, Schwann cells that line the ventral roots, adrenal chromaffin cells, pigment cells (melanocytes), cells from the adrenal medulla thyroid glands and the neurons of the enteric nervous system (ENS) (Le Douarin and Kalcheim, 1999). Besides the genetically encoded potentiality of NCCs to become a specific derivative, the final differentiation of these cells depends to a large extent on the environment through which they migrate and the cues that they receive. To reach their 
final destination NCCs emit and receive signals that are crucial to determine the path they go through. In the paragraphs below we explain in detail the signals and factors that modulate tNCCs migration.

In the three migratory pathways described before, the proteins laminin and fibronectin are permissive substrates for NC migration. In chick, fish and frog, one of the first cues that direct recently delaminated NCCs to go ventrally to the sclerotome is the chemokine Cxcl12, which attracts Cxcr4 expressing NCCs to the dorsal aorta (Fig. 3) (Gordon et al., 2011).

In mouse and chick, migrating tNCCs are restricted to the anterior sclerotome because they express the receptors Ephrin$\mathrm{A} / \mathrm{B}$ (Eph-A/B) while the posterior sclerotome expresses Ephrin-B ligands (Baker and Antin, 2003). Another restriction to the migration of NCCs in the somite is the expression pattern of semaphorins
(Sem). Dermomyotome cells express Sem3A, which prevents Neuropilin-1 positive NCCs from entering it (Fig. 3), while the caudal sclerotome expresses Sem3F, which restricts Neuropilin-2 expressing cells to the anterior part of the somite (Fig. 3) (Schwarz et al., 2009). The semaphorin guidance cue is potentiated by proteoglycans (F-spondin and Versicans) that are expressed in the caudal sclerotome (Casini et al., 2008). The role of Eph/Ephrin and semaphorin pathways in Xenopus and zebrafish tNC migration has not been assessed yet, thus providing an interesting field for future research.

The signaling Slit/Robo is essential in preventing tNCCs from entering the dorsolateral pathway and restricting them to the ventral one. The dermomyotome secretes the Slit protein, which prevents Robo-expressing NC from entering the dorsolateral pathway (Fig. 3) (Jia et al., 2005). Another recently found role of the Slit/Robo
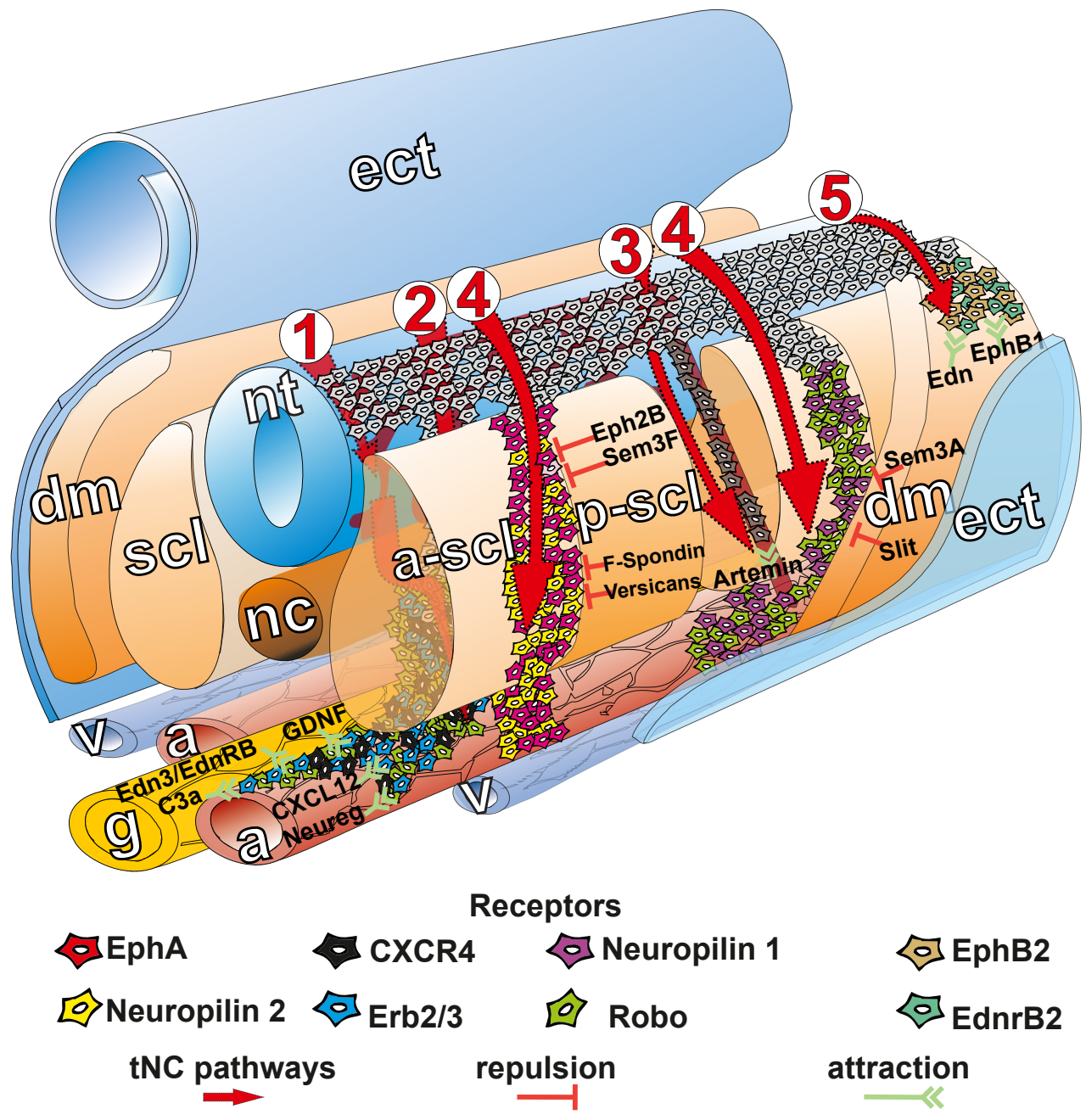

Fig. 3. Environmental cues guiding trunk neural crest migration. (1) After delaminating from the neural trunk, trunk neural crest cells (tNCCs) migrate along various streams. (2) Ventromedial pathway: cells expressing Cxcr4 are attracted by the ligand Cxcl12. Neuregulin attracts Enrb2/3 expressing cells. C3a and GDNF from the gut mesenchyme attracts cells expressing receptors C3ar and GFR 1, respectively. Also, endothelin3 is an attractant of cells expressing EdnrB. Finally, the Slit factor excludes Robo expressing cells from entering the gut. (3) Ventrally between the somites along intersomitic vessels, by Artemin atraction. (4a) Ventrolateral pathway across the somites: Eph2B and Sem3F signals repel EphA and Neuropilin1 expressing cells, respectively. (4b) Slit and Sem3A generate a repulsive signal from the dermomyotome to cells expressing Robo and Neuropilin1, respectively. This prevents cell migration from the sclerotome to the dermomyotome. (5) Dorsolateral pathway: NCCs along this pathway are attracted to migrate between the dermomyotome and the ectoderm by EphB1 and Endothelin proteins which attracts cells expressing EphB2 and EdnrB2 receptors, respectively. a, dorsal aorta; a-scl, anterior sclerotome; dm, dermomyotome; ect, ectoderm; g, gut; nc, notochord; nt, neural tube; p-scl, posterior sclerotome; v, vein. 
signaling is the restriction to the entrance of tNCCs into the developing gut. Slit expressing cells that are near the entrance to the gut generate a negative cue to migrating tNCCs that express the receptor Robo (Fig. 3) (Zuhdi et al., 2015).

The diffusible protein Draxin, which is better known for its role as an axon guidance molecule, has an inhibiting role as a signaling cue during chick and mouse NC migration. In the first wave of migration, Draxin expressed in the dorsal lip of the dermomyotome restricts early migrating $\mathrm{NC}$ cells from entering the dorsolateral pathway. This inhibitory function lies in the ability of Draxin to alter cell polarization by cytoskeleton remodeling (Zhang et al., 2016)

As expressed above, cadherins are important in the process of EMT and during the migration of trunk NCCs. In regard to the migration of NCCs through the anterior part of the sclerotome, T-cadherins are essential to reduce the adhesion of NCCs to the caudal sclerotome (Ranscht and Bronner-Fraser, 1991).

The cells that migrate along the ventrolateral pathway reaching the dorsal aorta are guided by four distinct signaling cues. Neuregulin from the mesenchyme around the dorsal aorta attracts Erb2/3 expressing NCCs to the ventral side to pass the sclerotome (Fig. 3) (Fantauzzo and Soriano, 2015). The second signal is the above mentioned Cxcl12 chemokine which attracts NCCs expressing Cxcr4 to the dorsal aorta. In addition to these signals, the neurotrophic factor Artemin, secreted by the peripheral blood vessel cells, attracts NC sympathetic precursors and allows their proliferation (Fig. 3, stream 3) (Honma et al., 2002). The fourth signal has a repulsive mechanism; Sem3A expressed in limbs, dermomyotome and notochord restricts Neuropilin-1 expressing NCCs near the dorsal aorta (Kawasaki et al., 2002).

Zebrafish $\mathrm{tNCCs}$ require Notch/Delta signaling. The trunk region contains an equivalence domain of cells that can become RohonBeard cells but, when exposed to Notch/Delta signaling, become tNC instead (McGraw et al., 2012). During their migration along the ventrolateral pathway, NC cells not only receive signals from the environment but also induce certain changes in neighboring tissues. For instance, tNCCs migrating underneath the dermomyotome trigger myogenesis by transiently activating Notch/Delta signaling in muscle precursors (Rios et al., 2011).

Apart from the vast evidence and information about the ventromedial pathway in mouse and chick, little is known about the particular molecular cues that guide Xenopus tNCCs to this ventromedial pathway. Further work is needed to understand the underlying mechanisms that govern the migration of Xenopus tNCCs.

Migration of tNCCs along the dorsolateral pathway is controlled by several signaling molecules. Cells that are determined to the melanocytic lineage upregulate Eph-B2 and are attracted to the dorsal ectoderm by Ephrin-B1 (Fig. 3) (Santiago and Erickson, 2002). The dorsolateral route contains Endothelins, which prevents EdnrB-expressing neuronal and glial precursors from entering the dorsolateral pathway and at the same time stimulate EdnrB2-expressing melanocytic precursors to the migration onto this pathway (Harris et al., 2008). In the case of the mouse, the kit ligand expressed in the dermomyotome attracts melanoblasts that express the kit receptor (Wehrle-Haller et al., 2001). Also in mouse, the chemokine Sdf1 guides the melanocytes from the skin to the hair follicle (Belmadani et al., 2009). Not only particular guidance molecules direct the migration of tNCCs but entire tissues do so as well. It has been shown that the emerging dermis supplies a yet uncharacterized diffusible attractant that stimulates melanoblasts to enter the dorsal pathway (Tosney, 2004)

In contrast to the vast quantity of cells that enter the dorsolateral pathway in mouse and chick, in Xenopus only a small portion of cells migrate through this pathway; they use the medial pathway instead and then move laterally, below the somites, to reach the epidermis (Collazo et al., 1993). In the case of zebrafish, NCCs use both the ventromedial and the dorsolateral pathway to form melanocyte derivatives (Kelsh et al., 2009).

The directionality of the migration of tNCCs cannot emerge only from a balance of positive and negative cues that promotes the invasion of specific areas of the embryo. The interplay between inhibiting signals and attracting cues cannot fully explain the overall directionality in the migration of tNCCs. Therefore, it is more likely that this directed migration is controlled on a local scale in between a certain migratory stream.

For this reason extensive research has been done to understand the molecular mechanisms that delineate the movements of the NCCs during their migration. In Xenopus laevis it has been shown that the collective migration of NCCs involve a combination of mechanisms, including contact inhibition of locomotion (CIL), repolarization, chemoattraction and coattraction, at least in the case of cranial NCCs. More specifically, it is known that NCCs are attracted to each other via ligand receptor interaction mediated by Complement3a (C3a) and the $\mathrm{C} 3 \mathrm{a}$ receptor (Broders-Bondon et al., 2016). These cells are also attracted by a secreted factor called SDF, which plays a key role in patterning NC cells into forward moving streams. This factor is expressed in the ectoderm facing the early migrating NCCs (Theveneau et al., 2010).

Recently, molecular level-studies and computational simulations were performed to analyze the intrinsic molecular signature within an NCC migratory stream. The results showed that there are regional differences in gene expression within a particular $\mathrm{NC}$ stream and that there is a consistent and stable molecular signature unique to the cells in the distal portion of the migratory stream (McLennan et al., 2015).

\section{Signaling pathways involved in the specification and differentiation of tNCCs}

After migrating along the three pathways mentioned before, the NCCs settle in discrete sites and differentiate into diverse cell types. This process of cell differentiation requires the deployment of differentiation gene batteries, which are sets of genes that confer its terminal identity to each cell (Erwin and Davidson, 2009). Gene batteries are controlled by different drivers, which are regulators that control the transition between the progenitor and differentiated states (Peter and Davidson, 2015). The SoxE transcription factors are important in activating differentiation gene batteries during NC differentiation. More particularly, Sox10 is involved in the differentiation of NCCs into neurons, glia and melanocytes (Kelsh, 2006), while Sox9 participates in the stimulation towards a chondrocyte fate (Mori-Akiyama et al., 2003). The misexpression of SOX10 during NC development in human causes WaardenburgHirschsprung disease (Pingault et al., 1998).

Since migratory NCCs are multipotent, environmental cues play a key role in determining the fate of their progeny. These cues are integrated by the signaling pathways that are active in the cells along the migratory route. In this section we describe the different molecules and signaling pathways involved in the differentiation 
of tNCCs into their particular derivatives.

Kit signaling is essential in the differentiation of NC into melanocytes (Parichy et al., 1999). Furthermore, MitfA and Sox10 are crucial to promote melanoblast specification. However, subsequently, MitfA-dependent activation of the histone deacetylase complex Hdac1 represses sox10 expression in melanoblasts, promoting both differentiation and fate commitment (Greenhill et al., 2011).

In addition, BMP has been shown to participate in the differentiation of cells into the autonomic nervous system lineage (Saito et al., 2012), whereas the Wnt pathway has been associated with the formation of sensory neurons and melanocytes (Lee et al., 2004). Another example of a signaling pathway responsible for the differentiation of NCCs is the Endothelin-receptor B signaling, which is required for enteric nerve cell formation and melanocyte development (Dupin and Le Douarin, 2003). It has been suggested that another receptor of the same family, the Endothelin receptor A, plays a key role in the induction of Xenopus laevis melanocytes (Bonano et al., 2008). Also in Xenopus, a study has shown that the Edn3-Ednrb2 signal is required for the migration of melanoblasts and that the receptor is expressed in melanoblast while the ligand Edn3 is expressed at the destination sites of their migration (Kawasaki-Nishihara et al., 2011).

Another signaling molecule important for the differentiation of tNC into a specific cell type is Retinoic Acid, which influences cells to develop as sympathetic neurons (Ito and Morita, 1995). Moreover, ErbB/Neuregulin signaling is involved in $\mathrm{tNC}$ migration and differentiation into DRG sensory neurons and sympathetic ganglia (Britsch et al., 1998).

Until now we have only discussed the signaling molecules and survival factors involved in the formation of trunk NC derivatives. However, these factors inevitably cooperate to activate a transcriptional cascade that in turn establishes the functional and morphological changes that are coincident with differentiation. For example, the transcription factor Achaete-scute homolog 1 (Ascl) is the first indicator of neuronal differentiation in the autonomic lineage (Groves et al., 1995). It is also a master proneural gene for the specification of the sympathetic lineage (Sommer et al., 1995). Another important regulator for the development of the autonomic nervous system is the transcription factor Phox $2 \mathrm{~b}$, which is hierarchically equivalent to Ascl1 (Pattyn et al., 1999). In regard to another aspect of PNS development, Hand1 and Hand2 transcription factors are important in the acquisition of noradrenergic characteristics among the peripheral system neurons (Morikawa et al., 2005). In the development of the sensory nervous system, signaling by the Trk receptors is of vital importance during the neurogenesis of the DRG (Fantauzzo and Soriano, 2015).

The enteric neural system (ENS) is formed from enteric NCCs (ENCCs) migrating from the vagal and sacral region, which colonize the entire length of the gut wall forming all the neurons of the enteric system. The ENS is sometimes called the "second brain" because of the diversity of neuronal cell types and complex, integrated circuits that permit the ENS to autonomously regulate many processes in the bowel (Panza et al., 2012). The signaling through the receptor tyrosine kinase gene, RET, is essential for ENS development (Panza et al., 2012). The receptors involved in this signaling are the glial cell line-derived neurotrophic factor (GDNF) and its glycosylphosphatidylinositol (GPI)-anchored coreceptor, GFR $\alpha 1$. Expression of Ret and Gra1 is activated in ENCCs upon entry into the foregut, whereas Gdnf is detected in gut mesenchyme prior to ENCCs arrival in the foregut (Natarajan et al., 2002). The Endothelin B signaling pathway through the Endothelin 3 ligand and the EdnrB receptor has also a very important role in the development of the ENS, for the mutation in the genes of these proteins delay colonization in the gut (Lee et al., 2003)

Even though knowledge about the differentiation mechanisms in the NC is continuously growing, further work is required to address all the steps necessary to transform a multipotent migratory $\mathrm{NC}$ cell into a differentiated progenitor.

\section{NCCs and tumor cells: two distinct but similar cell populations}

Cancer cells use certain molecular and genetic tools similar to developing NCCs. Malignant cells mimic many of the behavioral, genetic, molecular and morphological aspects of NC development (Karunasena et al., 2015, Kerosuo and Bronner-Fraser, 2012, Maguire et al., 2015, Nguyen et al., 2009).

In cancer cells, TGF $\beta$ and Wnt are upregulated. There is also an increase in the signaling by tyrosine kinase receptors (Thiery and Sleeman, 2006). These upregulated signaling pathways are reminiscent of the BMP, Wnt and FGF signals implicated in NC induction and the BMP/Wnt cascade that triggers the EMT. In addition, the Hippo/Yap signaling, which has known roles in the migration of cancer cells, has recently been described as promoting an early NC phenotype (multipotency) and migration which occur during human NC development (Hindley et al., 2016, Uribe and Bronner, 2015). This emphasizes the relationship between NC development and cancer progression.

After delaminating from their original place, NCCs and tumor cells undergo solitary and collective cell migration. Both of these cell types use existing tissues and cellular structures to migrate and colonize new territory; i.e. tumor cells migrate along nerves and use blood vessels to disseminate (Nguyen et al., 2009), while NCCs use the basement membrane of the ectoderm and dermomyotome and also migrate along nerves (Hall, 2008).

Besides the fact that cancer cells are similar to NCCs, there is a group of cancers that are direct descendants of NCCs, some of which are described below. One example is the group of tumors from the sympathetic ganglia lineage known as neuroblastomas and ganglioneuromas, which evidence a high expression of the Hedgehog signaling pathway (Gershon et al., 2009) or TrkB/ BDNF signaling (Gryz and Meakin, 2003). Paragangliomas and pheochromocytomas are highly vascularized tumors arising from NC-derived tissues in the paraxial autonomic ganglia or in the chromaffin cells of the adrenal medulla, respectively (Dahan et al., 2005). One of the best known cancers derived from the NC are malignant melanomas, which arise from the melanocytic lineage (Davies et al., 2002). Neurofibromatosis consists of tumors that are derived from Schwann cells and are genetically inherited (Evans et al., 2010).

The use of embryonic models and particularly NCCs to study tumor cell phenotype determination affords an innovative approach for investigating the boundaries of tumor cell plasticity and the potential for reprogramming deadly cell types by targeting the convergence of embryonic and tumorigenic signaling pathways. A common problem in the testing of clinical drugs is that it is a long and expensive process limited only to cultured cancer cells or artificial tumor models. However, embryos from model organisms 
can serve as a unique in vivo system for screening the effects of specific factors or for high-throughput screening of small molecule libraries (Maguire et al., 2015).

Cancer treatments at present include surgery, chemotherapy, and radiation therapy, all of which are done at the cost of a lower quality of life. It is of extreme importance to design therapies that reduce collateral damage. Targeting signaling factors and processes have proven very effective; small molecule inhibitors of Snail (Azmi et al., 2013) or c-Myc (Muller et al., 2014) are being tested for their therapeutic potential. There is also a wide field of research in the targeting of hedgehog signaling molecules for cancer treatment (Abidi, 2014). Moreover, recent efforts are aimed at identifying inhibitors of EMT in order to inhibit the invasive capacity of cancer cells (Chua et al., 2012).

With a growing capacity to target particular signaling pathways and molecules we will be able to tackle several pathologies imposed by this disease. Given the above results and evidence, it is important to say that the understanding of NC development can have potentially important implications for the treatment of several types of cancers.

\section{NCCs as stem cells: characteristics and potential ap- plications}

Due to the amazingly diversified array of cell types that they generate, tNCCs represent an attractive model in the stem cell field. The tNC population has multipotent and bipotent cells endowed with self-renewal, a bona fide property of stem cells. These cells have the potency to yield glial cells, autonomic neurons and myofibroblast/smooth muscle cells as well as melanocytes (Bittencourt et al., 2013). They are called NC stem cells (NCSCs) (Achilleos and Trainor, 2012). These cells were first isolated from mammalian multipotent NCCs taking advantage of the expression of the p75 marker (Stemple and Anderson, 1992).

In rat and mouse, BMP and Wnt signaling are involved in the maintenance of the undifferentiated state of NCCs (Kleber et al., 2005). The transcription factor Sox10, which is expressed in premigratory and migratory NCCs, functions in the maintenance of multipotentiality of these cells both in vitro and in vivo (Kim et al., 2003). Other regulators that control the pluripotent capacity of NCCs are the chromatin remodelers CHD7 and SWI/SNF-B, which act in conjunction with BMP and Wnt signaling (Fujita et al., 2014). NCSCs are found not only in premigratory NCCs, but also in NC derivatives such as the peripheral nerve, the DRG and the gut, demonstrating that the migratory stream of some NC populations are a mixture of specified and multipotent cells (Morrison et al., 1999).

It has recently been shown in Xenopus laevis that, through the process of gastrulation, NCCs retain pluripotency factors inherited from stem cells of the blastula stage. These are the Snail 1 and Sox5 factors, which are responsible for keeping the developmental capacities characteristic of NCCs (Buitrago-Delgado et al., 2015).

Major advances in this area have allowed scientists to unravel the specific molecules responsible for favoring a specific NC lineage, taking as a source NCSCs. Such is the case for TGF $\beta$, BMP4, Neuregulin-1, Retinoic Acid, Edn3 and Delta-1, all of which favor the development of specific NC sublineages in an instructive or permissive manner (Le Douarin and Dupin, 2016).

A major breakthrough in NC biology has occurred recently, with scientists being able to differentiate human pluripotent stem cells (hPSC) into subtype specific NC cells, namely trunk NCCs (in the presence of Retinoic Acid) and cranial NCCs (in the absence of Retinoic Acid) (Huang et al., 2016). This discovery offers a renewable human cell model to study NC biology and to develop therapies against diseases arising from abnormal NC formation.

Therefore, the study of NC derived stem cells is of crucial importance because of their capacity to give rise to fully differentiated and functional cell types, which contributes to the development of regenerative medicine.

\section{Concluding remarks}

Fifteen years ago, many people argued that tNC played could play a pivotal role in the development and differentiation of sensory neurons and glia of the peripheral nervous system as well as in the differentiation of adenomedullary cells and pigment cells of the skin. Nowadays, advances in visualization and embryonic manipulation technologies have allowed us to understand the mechanisms that underlie the formation of the tNC in a much deeper way, thus making possible a more specific assessment of the key role of the $\mathrm{tNC}$ in the development of the peripheral and enteric nervous system. However, the ability of tNC to generate neural derivatives is not unique to this axial level, but instead is shared by all crest cells. This ability, as well as with all other crest potentials, is modulated by environmental cues.

Importantly, elucidating how and when different cues are expressed and discovering the interacting proteins during the formation, migration and differentiation of the trunk NC will contribute to our overall knowledge of the molecular basis of tNC formation. Dissecting these and many other key issues will yield important insights into the molecular control of NCCs development and help to define the pathogenesis of various developmental abnormalities (human disorders, diseases and syndromes) that occur upon aberrant $\mathrm{tNC}$ development. Also, identification of the signals required for trunk NCCs formation will facilitate ways to generate hESCs, which will be beneficial for the application of NCCs to regenerative medicine.

Thus, today our views of the significance of the tNC have changed. Continued attention to these areas should unveil numerous key players in the regulation of NCCs formation and development over the next few years. Future research will focus on understanding how these diverse signals work together to pattern trunk NCCs. Further investigation into these questions will clarify the mechanisms that dictate patterned tNC migration and segmental peripheral nervous development.

\section{Acknowledgments}

We are grateful to our colleagues for helpful discussions. This publication was supported by grants from ANPCyT-Foncyt to M.J.A. (PICT2013-1686 and PICT2015-1207), and by grants from CIUNT to M.J.A. (PIUNT 26/ D506). We specially thank to Ms. Virginia Mendez for proofreading and Mr. Elias Maza and Mrs. Daniela Maza for their help with the graphics. We regret that a lot of specific publications dealing with the subject of this review could not be cited due to space limitations.

\section{References}

ABIDI, A. (2014). Hedgehog signaling pathway: a novel target for cancer therapy: vismodegib, a promising therapeutic option in treatment of basal cell carcinomas. 
Indian J Pharmacol 46: 3-12.

ACHILLEOS, A. and TRAINOR, P.A. (2012). Neural crest stem cells: discovery, properties and potential for therapy. Cell Res 22: 288-304.

AHLSTROM, J.D. and ERICKSON, C.A. (2009). The neural crest epithelial-mesenchymal transition in 4D: a 'tail' of multiple non-obligatory cellular mechanisms. Development 136: 1801-1812.

AYBAR, M.J. and MAYOR, R. (2002). Early induction of neural crest cells: lessons learned from frog, fish and chick. Curr Opin Genet Dev 12: 452-458.

AZMI, A.S., BOLLIG-FISCHER, A., BAO, B., PARK, B.J., LEE, S.H., YONG-SONG, G., DYSON, G., REDDY, C.K., SARKAR, F.H. and MOHAMMAD, R.M. (2013). Systems analysis reveals a transcriptional reversal of the mesenchymal phenotype induced by SNAIL-inhibitor GN-25. BMC systems biology 7: 85.

BAGGIOLINI, A., VARUM, S., MATEOS, J.M., BETTOSINI, D., JOHN, N., BONALLI, M., ZIEGLER, U., DIMOU, L., CLEVERS, H., FURRER, R. et al., (2015). Premigratory and migratory neural crest cells are multipotent in vivo. Cell Stem Cell16:314-322.

BAKER, R.K. and ANTIN, P.B. (2003). Ephs and ephrins during early stages of chick embryogenesis. Dev Dyn 228: 128-142.

BELMADANI, A., JUNG, H., REN, D. and MILLER, R.J. (2009). The chemokine SDF-1/CXCL12 regulates the migration of melanocyte progenitors in mouse hair follicles. Differentiation 77: 395-411

BETANCUR, P., BRONNER-FRASER, M. and SAUKA-SPENGLER, T. (2010a). Assembling neural crest regulatory circuits into a gene regulatory network. Annu Rev Cell Dev Biol 26: 581-603.

BETANCUR, P., BRONNER-FRASER, M. and SAUKA-SPENGLER, T. (2010b). Genomic code for Sox10 activation reveals a key regulatory enhancer for crania neural crest. Proc Natl Acad Sci USA 107: 3570-3575.

BITTENCOURT, D.A., DA COSTA, M.C., CALLONI, G.W., ALVAREZ-SILVA, M. and TRENTIN, A.G. (2013). Fibroblast growth factor 2 promotes the self-renewal of bipotent glial smooth muscle neural crest progenitors. Stem Cells Dev22: 1241-1251.

BONANO, M., TRIBULO, C., DE CALISTO, J., MARCHANT, L., SANCHEZ, S.S., MAYOR, R. and AYBAR, M.J. (2008). A new role for the Endothelin-1/Endothelin-A receptor signaling during early neural crest specification. Dev Biol323: 114-129.

BRITSCH, S., LI, L., KIRCHHOFF, S., THEURING, F., BRINKMANN, V., BIRCHMEIER, C. and RIETHMACHER, D. (1998). The ErbB2 and ErbB3 receptors and their ligand, neuregulin-1, are essential for development of the sympathetic nervous system. Genes Dev 12: 1825-1836.

BRODERS-BONDON, F., PAUL-GILLOTEAUX, P., GAZQUEZ, E., HEYSCH, J., PIEL, M., MAYOR, R., LAMBRIS, J.D. and DUFOUR, S. (2016). Control of the collective migration of enteric neural crest cells by the Complement anaphylatoxin C3a and N-cadherin. Dev Biol 414: 85-99.

BRONNER, M. (2015). Confetti clarifies controversy: neural crest stem cells are multipotent. Cell Stem Cell 16: 217-218.

BUITRAGO-DELGADO, E., NORDIN, K., RAO, A., GEARY, L. and LABONNE, C. (2015). NEURODEVELOPMENT. Shared regulatory programs suggest retention of blastula-stage potential in neural crest cells. Science 348: 1332-1335.

CASINI, P., ORI, M., AVENOSO, A., D'ASCOlA, A., TRAINA, P., MATTINA, W., PERRIS, R., CAMPO, G.M., CALATRONI, A., NARDI, I. et al., (2008). Identification and gene expression of versican during early development of Xenopus. Int J Dev Biol 52: 993-998.

COLLAZO, A., BRONNER-FRASER, M. and FRASER, S.E. (1993). Vital dye labelling of Xenopus laevis trunk neural crest reveals multipotency and novel pathways of migration. Development 118: 363-376.

CHEUNG, M., CHABOISSIER, M.C., MYNETT, A., HIRST, E., SCHEDL, A. and BRISCOE, J. (2005). The transcriptional control of trunk neural crest induction, survival, and delamination. Dev Cell 8: 179-192.

CHUA, K.N., SIM, W.J., RACINE, V., LEE, S.Y., GOH, B.C. and THIERY, J.P. (2012). A cell-based small molecule screening method for identifying inhibitors of epithelialmesenchymal transition in carcinoma. PLoS One 7: e33183.

DAHAN, L., ATLAN, D., BOUCHE, O., MITRY, E., RIES, P., ARTRU, P., RICHARD, K., LLEDO, G., NGUYEN, T., ROUGIER, P. et al., (2005). Postoperative chemoradiotherapy after surgical resection of gastric adenocarcinoma: can LV5FU2 reduce the toxic effects of the MacDonald regimen? A report on 23 patients. Gastroenterol. Clin. Biol. 29: 11-15.

DAVIES, T.W., TREASURE, F.P., WELCH, A.A. and DAY, N.E. (2002). Diet and basal cell skin cancer: results from the EPIC-Norfolk cohort. Br. J. Dermatol. 146: 1017-1022.
DUBAND, J.L., MONIER, F., DELANNET, M. and NEWGREEN, D. (1995). Epitheliummesenchyme transition during neural crest development. Acta Anat (Basel) 154 63-78.

DUPIN, E. and LE DOUARIN, N.M. (2003). Development of melanocyte precursors from the vertebrate neural crest. Oncogene 22: 3016-3023.

DUPIN, E. and SOMMER, L. (2012). Neural crest progenitors and stem cells: from early development to adulthood. Dev Biol 366: 83-95.

DYACHUK, V., FURLAN, A., SHAHIDI, M.K., GIOVENCO, M., KAUKUA, N., KONSTANTINIDOU, C., PACHNIS, V., MEMIC, F., MARKLUND, U., MULLER, T. et al., (2014). Neurodevelopment. Parasympathetic neurons originate from nerveassociated peripheral glial progenitors. Science 345: 82-87.

ERICKSON, C.A., DUONG, T.D. and TOSNEY, K.W. (1992). Descriptive and experimental analysis of the dispersion of neural crest cells along the dorsolatera path and their entry into ectoderm in the chick embryo. Dev Biol 151: 251-272.

ERWIN, D.H. and DAVIDSON, E.H. (2009). The evolution of hierarchical gene regulatory networks. Nature Review Genet.10: 141-148.

ETCHEVERS, H.C., AMIEL, J. and LYONNET, S. (2006). Molecular bases of human neurocristopathies. Adv. Exp. Med. Biol. 589: 213-234.

ETCHEVERS, H.C., VINCENT, C., LE DOUARIN, N.M. and COULY, G.F. (2001) The cephalic neural crest provides pericytes and smooth muscle cells to all blood vessels of the face and forebrain. Development 128: 1059-1068.

EVANS, D.G., HOWARD, E., GIBLIN, C., CLANCY, T., SPENCER, H., HUSON S.M. and LALLOO, F. (2010). Birth incidence and prevalence of tumor-prone syndromes: estimates from a UK family genetic register service. Am. J. Med. Genet. Part A 152A: 327-332.

FANTAUZZO, K.A. and SORIANO, P. (2015). Receptor tyrosine kinase signaling: regulating neural crest development one phosphate at a time. Curr Top Dev Biol 111: 135-182.

FERNANDEZ, J.P., AGUERO, T.H., VEGA LOPEZ, G.A., MARRANZINO, G., CERRIZUELA, S. and AYBAR, M.J. (2014). Developmental expression and role of Kinesin Eg5 during Xenopus laevis embryogenesis. Dev Dyn 243: 527-540.

FUJITA, K., OGAWA, R., KAWAWAKI, S. and ITO, K. (2014). Roles of chromatin remodelers in maintenance mechanisms of multipotency of mouse trunk neural crest cells in the formation of neural crest-derived stem cells. Mech Dev 133: 126-145.

GAMMILL, L.S. and ROFFERS-AGARWAL, J. (2010). Division of labor during trunk neural crest development. Dev Biol 344: 555-65

GERSHON, T.R., SHIRAZ, A., QIN, L.X., GERALD, W.L., KENNEY, A.M. and CHEUNG, N.K. (2009). Enteric neural crest differentiation in ganglioneuromas implicates Hedgehog signaling in peripheral neuroblastic tumor pathogenesis. PLoS One 4: e7491.

GONG, S.G. (2014). Cranial neural crest: migratory cell behavior and regulatory networks. Exp Cell Res 325: 90-95.

GORDON, C.T., WADE, C., BRINAS, I. and FARLIE, P.G. (2011). CXCL14 expression during chick embryonic development. Int J Dev Biol 55: 335-340.

GREENHILL, E.R., ROCCO, A., VIBERT, L., NIKAIDO, M. and KELSH, R.N. (2011) An iterative genetic and dynamical modelling approach identifies novel features of the gene regulatory network underlying melanocyte development. PLoS Genet 7: e1002265

GROVES, A.K., GEORGE, K.M., TISSIER-SETA, J.-P., ENGEL, J.D., BRUNET, J.-F. and ANDERSON, D.J. (1995). Differential regulation of transcription factor gene expression and phenotypic markers in developing sympathetic neurons. Development 121: 887-901.

GRYZ, E.A. and MEAKIN, S.O. (2003). Acidic substitution of the activation loop tyrosines in TrkA supports nerve growth factor-dependent, but not nerve growth factor-independent, differentiation and cell cycle arrest in the human neuroblastoma cell line, SY5Y. Oncogene 22: 8774-85

HALL, B.K. (2008). The neural crest and neural crest cells: discovery and significance for theories of embryonic organization. J. Biosci. 33: 781-93.

HARRIS, M.L., HALL, R. and ERICKSON, C.A. (2008). Directing pathfinding along the dorsolateral path - the role of EDNRB2 and EphB2 in overcoming inhibition. Development 135: 4113-22.

HINDLEY, C.J., CONDURAT, A.L., MENON, V., THOMAS, R., AZMITIA, L.M., DAVIS J.A. and PRUSZAK, J. (2016). The Hippo pathway member YAP enhances human neural crest cell fate and migration. Sci Rep 6: 23208.

HONJO, Y. and EISEN, J.S. (2005). Slow muscle regulates the pattern of trunk neura 
crest migration in zebrafish. Development 132: 4461-70.

HONMA, Y., ARAKI, T., GIANINO, S., BRUCE, A., HEUCKEROTH, R., JOHNSON, E. and MILBRANDT, J. (2002). Artemin is a vascular-derived neurotropic factor for developing sympathetic neurons. Neuron 35: 267-282.

HUANG, M., MILLER, M.L., MCHENRY, L.K., ZHENG, T., ZHEN, Q., ILKHANIZADEH, S., CONKLIN, B.R., BRONNER, M.E. and WEISS, W.A. (2016). Generating trunk neural crest from human pluripotent stem cells. Sci Rep 6: 19727.

ITO, K. and MORITA, T. (1995). Role of retinoic acid in mouse neural crest cell development in vitro. Dev Dyn 204: 211-8.

JIA, L., CHENG, L. and RAPER, J. (2005). Slit/Robo signaling is necessary to confine early neural crest cells to the ventral migratory pathway in the trunk. Dev Biol 282: 411-21.

KARUNASENA, E., MCIVER, L.J., BAVARVA, J.H., WU, X., ZHU, H. and GARNER, H.R. (2015). "Cut from the same cloth": Shared microsatellite variants among cancers link to ectodermal tissues-neural tube and crest cells. Oncotarget 8:22038-22047.

KAWASAKI-NISHIHARA, A., NISHIHARA, D., NAKAMURA, H. and YAMAMOTO, H. (2011). ET3/Ednrb2 signaling is critically involved in regulating melanophore migration in Xenopus. Dev Dyn 240: 1454-1466.

KAWASAKI, T., BEKKU, Y., SUTO, F., KITSUKAWA, T., TANIGUCHI, M., NAGATSU, I., NAGATSU, T., ITOH, K., YAGI, T. and FUJISAWA, H. (2002). Requirement of neuropilin 1-mediated Sema3A signals in patterning of the sympathetic nervous system. Development 129: 671-680.

KELSH, R.N. (2006). Sorting out Sox10 functions in neural crest development. Bioessays 28: 788-798.

KELSH, R.N., HARRIS, M.L., COLANESI, S. and ERICKSON, C.A. (2009). Stripes and belly-spots -- a review of pigment cell morphogenesis in vertebrates. Semin Cell Dev Biol 20: 90-104.

KEROSUO, L. and BRONNER-FRASER, M. (2012). What is bad in cancer is good in the embryo: importance of EMT in neural crest development. Semin Cell Dev Biol 23: 320-332.

KIM, J., LO, L., DORMAND, E. and ANDERSON, D.J. (2003). SOX10 maintains multipotency and inhibits neuronal differentiation of neural crest stem cells. Neuron 38: 17-31.

KLEBER, M., LEE, H.Y., WURDAK, H., BUCHSTALLER, J., RICCOMAGNO, M.M., ITTNER, L.M., SUTER, U., EPSTEIN, D.J. and SOMMER, L. (2005). Neural crest stem cell maintenance by combinatorial Wnt and BMP signaling. J Cell Biol 169: 309-320.

KRISPIN, S., NITZAN, E., KASSEM, Y. and KALCHEIM, C. (2010). Evidence for a dynamic spatiotemporal fate map and early fate restrictions of premigratory avian neural crest. Development 137: 585-95.

KULESA, P.M., BAILEY, C.M., KASEMEIER-KULESA, J.C. and MCLENNAN, R. (2010). Cranial neural crest migration: new rules for an old road. Dev Biol 344: 543-554.

KUO, B.R. and ERICKSON, C.A. (2010). Regional differences in neural crest morphogenesis. Cell Adh Migr 4: 567-585.

KUO, B.R. and ERICKSON, C.A. (2011). Vagal neural crest cell migratory behavior: A transition between the cranial and trunk crest. Dev Dyn 240: 2084-2100.

KURIYAMA, S. and MAYOR, R. (2008). Molecular analysis of neural crest migration. Philos Trans R Soc Lond B Biol Sci 363: 1349-1362.

LE DOUARIN, N. and KALCHEIM, C. (1999). The neural crest. Cambridge University Press.

LE DOUARIN, N.M. and DUPIN, E. (2016). Chapter Thirty-Eight-The Pluripotency of Neural Crest Cells and Their Role in Brain Development. Curr Top Dev Biol 116: 659-678.

LEE, H.O., LEVORSE, J.M. and SHIN, M.K. (2003). The endothelin receptor-B is required for the migration of neural crest-derived melanocyte and enteric neuron precursors. Dev Biol 259: 162-175.

LEE, H.Y., KLEBER, M., HARI, L., BRAULT, V., SUTER, U., TAKETO, M.M., KEMLER, R. and SOMMER, L. (2004). Instructive role of Wnt/beta-catenin in sensory fate specification in neural crest stem cells. Science 303: 1020-1023.

LIU, J.A., WU, M.H., YAN, C.H., CHAU, B.K., SO, H., NG, A., CHAN, A., CHEAH, K.S., BRISCOE, J. and CHEUNG, M. (2013). Phosphorylation of Sox 9 is required for neural crest delamination and is regulated downstream of BMP and canonical Wnt signaling. Proc Natl Acad Sci USA 110: 2882-2887.

LUMSDEN, A. and GUTHRIE, S. (1991). Alternating patterns of cell surface properties and neural crest cell migration during segmentation of the chick hindbrain.
Dev Supp/ Suppl 2: 9-15.

MAGUIRE, L.H., THOMAS, A.R. and GOLDSTEIN, A.M. (2015). Tumors of the neural crest: Common themes in development and cancer. Dev Dyn 244: 311-322.

MCGRAW, H.F., SNELSON, C.D., PRENDERGAST, A., SULI, A. and RAIBLE, D.W. (2012). Postembryonic neuronal addition in Zebrafish dorsal root ganglia is regulated by Notch signaling. Neural Dev 7: 1-13.

MCKINNEY, M.C., FUKATSU, K., MORRISON, J., MCLENNAN, R., BRONNER, M.E. and KULESA, P.M. (2013). Evidence for dynamic rearrangements but lack of fate or position restrictions in premigratory avian trunk neural crest. Development 140: 820-830.

MCLENNAN, R., DYSON, L., PRATHER, K.W., MORRISON, J.A., BAKER, R.E., MAINI, P.K. and KULESA, P.M. (2012). Multiscale mechanisms of cell migration during development: theory and experiment. Development 139: 2935-2944.

MCLENNAN, R., SCHUMACHER, L.J., MORRISON, J.A., TEDDY, J.M., RIDENOUR, D.A., BOX, A.C., SEMERAD, C.L., LI, H., MCDOWELL, W., KAY, D. et al., (2015). Neural crest migration is driven by a few trailblazer cells with a unique molecular signature narrowly confined to the invasive front. Development 142: 2014-2025.

MINOUX, M. and RIJLI, F.M. (2010). Molecular mechanisms of cranial neural crest cell migration and patterning in craniofacial development. Development 137:2605-2621.

MORI-AKIYAMA, Y., AKIYAMA, H., ROWITCH, D.H. and DE CROMBRUGGHE, B. (2003). Sox9 is required for determination of the chondrogenic cell lineage in the cranial neural crest. Proc Natl Acad Sci USA 100: 9360-9365.

MORIKAWA, Y., DAI, Y.S., HAO, J., BONIN, C., HWANG, S. and CSERJESI, P. (2005). The basic helix-loop-helix factor Hand2 regulates autonomic nervous system development. Dev. Dynam. 234: 613-621.

MORRISON, S.J., WHITE, P.M., ZOCK, C. and ANDERSON, D.J. (1999). Prospective identification, isolation by flow cytometry, and in vivo self-renewal of multipotent mammalian neural crest stem cells. Cell 96: 737-749.

MUKENDI, C., DEAN, N., LALA, R., SMITH, J., BRONNER, M.E. and NIKITINA, N.V. (2016). Evolution of the vertebrate claudin gene family: insights from a basal vertebrate, the sea lamprey. Int J Dev Biol 60: 39-51.

MULLER, I., LARSSON, K., FRENZEL, A., OLIYNYK, G., ZIRATH, H., PROCHOWNIK, E.V., WESTWOOD, N.J. and HENRIKSSON, M.A. (2014). Targeting of the MYCN protein with small molecule c-MYC inhibitors. PLoS One 9: e97285.

NAKAGAWA, S. and TAKEICHI, M. (1995). Neural crest cell-cell adhesion controlled by sequential and subpopulation-specific expression of novel cadherins. Development 121: 1321-1332.

NATARAJAN, D., MARCOS-GUTIERREZ, C., PACHNIS, V. and DE GRAAFF, E. (2002). Requirement of signalling by receptor tyrosine kinase RET for the directed migration of enteric nervous system progenitor cells during mammalian embryogenesis. Development 129: 5151-5160.

NGUYEN, D.X., BOS, P.D. and MASSAGUE, J. (2009). Metastasis: from dissemination to organ-specific colonization. Nat Rev Cancer 9: 274-284.

NIEHRS, C. (2004). Regionally specific induction by the Spemann-Mangold organizer. Nat Rev Genet 5: 425-434

NIETO, M.A. (2009). Epithelial-Mesenchymal Transitions in development and disease: old views and new perspectives. Int J Dev Biol 53: 1541-1547.

NITZAN, E., KRISPIN, S., PFALTZGRAFF, E.R., KLAR, A., LABOSKY, P.A. and KALCHEIM, C. (2013). A dynamic code of dorsal neural tube genes regulates the segregation between neurogenic and melanogenic neural crest cells. Development 140: 2269-2279.

OSORIO, L., TEILLET, M.A., PALMEIRIM, I. and CATALA, M. (2009). Neural crest ontogeny during secondary neurulation: a gene expression pattern study in the chick embryo. Int J Dev Biol 53: 641-648.

PANZA, E., KNOWLES, C.H., GRAZIANO, C., THAPAR, N., BURNS, A.J., SERI, M., STANGHELLINI, V. and DE GIORGIO, R. (2012). Genetics of human enteric neuropathies. Prog. Neurobiol. 96: 176-189.

PARICHY, D.M., RAWLS, J.F., PRATT, S.J., WHITFIELD, T.T. and JOHNSON, S.L. (1999). Zebrafish sparse corresponds to an orthologue of c-kit and is required for the morphogenesis of a subpopulation of melanocytes, but is not essential for hematopoiesis or primordial germ cell development. Development 126:3425-3436.

PATTYN, A., MORIN, X., CREMER, H., GORIDIS, C. and BRUNET, J.F. (1999). The homeobox gene Phox $2 b$ is essential for the development of autonomic neural crest derivatives. Nature 399: 366-370.

PETER, I. and DAVIDSON, E.H. (2015). Genomic control process: development and 
evolution. Academic Press.

PINGAULT, V., BONDURAND, N., KUHLBRODT, K., GOERICH, D.E., PRÉHU, M.-O., PULITI, A., HERBARTH, B., HERMANS-BORGMEYER, I., LEGIUS, E. and MATTHIJS, G. (1998). SOX10 mutations in patients with Waardenburg-Hirschsprung disease. Nat Genet 18: 171-173.

POWELL, D.R., WILLIAMS, J.S., HERNANDEZ-LAGUNAS, L., SALCEDO, E., O'BRIEN, J.H. and ARTINGER, K.B. (2015). Cdon promotes neural crest migration by regulating N-cadherin localization. Dev Biol 407: 289-299.

RAIBLE, D.W., WOOD, A., HODSDON, W., HENION, P.D., WESTON, J.A. and EISEN, J.S. (1992). Segregation and early dispersal of neural crest cells in the embryonic zebrafish. Dev Dyn 195: 29-42.

RANSCHT, B. and BRONNER-FRASER, M. (1991). T-cadherin expression alternates with migrating neural crest cells in the trunk of the avian embryo. Development 111: 15-22.

RICHARDSON, J., GAUERT, A., BRIONES MONTECINOS, L., FANLO, L., ALHASHEM, Z.M., ASSAR, R., MARTI, E., KABLA, A., HARTEL, S. and LINKER, C. (2016). Leader Cells Define Directionality of Trunk, but Not Cranial, Neural Crest Cell Migration. Cell Rep 15: 2076-2088.

RIOS, A.C., SERRALBO, O., SALGADO, D. and MARCELLE, C. (2011). Neural crest regulates myogenesis through the transient activation of $\mathrm{NOTCH}$. Nature 473: $532-535$

ROGERS, C.D., SAXENA, A. and BRONNER, M.E. (2013). Sip1 mediates an Ecadherin-to-N-cadherin switch during cranial neural crest EMT. J Cell Biol 203: 835-847.

SAITO, D., TAKASE, Y., MURAI, H. and TAKAHASHI, Y. (2012). The dorsal aorta initiates a molecular cascade that instructs sympatho-adrenal specification. Science 336: 1578-1581.

SANTIAGO, A. and ERICKSON, C.A. (2002). Ephrin-B ligands play a dual role in the control of neural crest cell migration. Development 129: 3621-3632.

SCHWARZ, Q., MADEN, C.H., VIEIRA, J.M. and RUHRBERG, C. (2009). Neuropilin 1 signaling guides neural crest cells to coordinate pathway choice with cell specification. Proc Natl Acad Sci USA 106: 6164-6169.

SERBEDZIJA, G.N., FRASER, S.E. and BRONNER-FRASER, M. (1990). Pathways of trunk neural crest cell migration in the mouse embryo as revealed by vital dye labelling. Development 108: 605-612.

SHOVAL, I., LUDWIG, A. and KALCHEIM, C. (2007). Antagonistic roles of full-length $\mathrm{N}$-cadherin and its soluble BMP cleavage product in neural crest delamination. Development 134: 491-501.

SIMKIN, J.E., ZHANG, D., ROLLO, B.N. and NEWGREEN, D.F. (2013). Retinoic Acid Upregulates Ret and Induces Chain Migration and Population Expansion in Vagal Neural Crest Cells to Colonise the Embryonic Gut. PLoS One 8: e64077.

SIMOES-COSTA, M.S., MCKEOWN, S.J., TAN-CABUGAO, J., SAUKA-SPENGLER, T. and BRONNER, M.E. (2012). Dynamic and differential regulation of stem cell factor FoxD3 in the neural crest is Encrypted in the genome. PLoS Genet 8: e1003142.
SOMMER, L., SHAH, N., RAO, M. and ANDERSON, D.J. (1995). The cellular function of MASH1 in autonomic neurogenesis. Neuron 15: 1245-1258.

SQUARE, T., JANDZIK, D., CATTELL, M., HANSEN, A. and MEDEIROS, D.M. (2016). Embryonic expression of endothelins and their receptors in lamprey and frog reveals stem vertebrate origins of complex Endothelin signaling. Sci Rep6:34282.

STEMPLE, D.L. and ANDERSON, D.J. (1992). Isolation of a stem cell for neurons and glia from the mammalian neural crest. Cell 71: 973-985.

SZABO, A. and MAYOR, R. (2016). Modelling collective cell migration of neural crest Curr. Opin. Cell Biol. 42: 22-28.

TANEYHILL, L.A. (2008). To adhere or not to adhere: the role of Cadherins in neura crest development. Cell Adh Migr 2: 223-230.

TAYLOR, K.M. and LABONNE, C. (2007). Modulating the activity of neural crest regulatory factors. Curr Opin Genet Dev 17: 326-31.

THEVENEAU, E., DUBAND, J.L. and ALTABEF, M. (2007). Ets-1 confers cranial features on neural crest delamination. PLoS One 2: e1142.

THEVENEAU, E., MARCHANT, L., KURIYAMA, S., GULL, M., MOEPPS, B., PARSONS M. and MAYOR, R. (2010). Collective chemotaxis requires contact-dependent cell polarity. Dev Cell 19: 39-53.

THIERY, J.P. and SLEEMAN, J.P. (2006). Complex networks orchestrate epithelialmesenchymal transitions. Nat Rev Mol Cell Biol 7: 131-142.

TOSNEY, K.W. (2004). Long-distance cue from emerging dermis stimulates neural crest melanoblast migration. Dev Dyn 229: 99-108.

URIBE, R.A. and BRONNER, M.E. (2015). Meis3 is required for neural crest invasion of the gut during zebrafish enteric nervous system development. Mol Biol Cell 26: 3728-3740.

VALLIN, J., GIRAULT, J.M., THIERY, J.P. and BRODERS, F. (1998). Xenopus cadherin-11 is expressed in different populations of migrating neural crest cells. Mech Dev 75: 171-174.

WEHRLE-HALLER, B., MELLER, M. and WESTON, J.A. (2001). Analysis of melanocyte precursors in Nf1 mutants reveals that MGF/KIT signaling promotes directed cell migration independent of its function in cell survival. Dev Biol 232: 471-483.

WYNN, M.L., RUPP, P., TRAINOR, P.A., SCHNELL, S. and KULESA, P.M. (2013) Follow-the-leader cell migration requires biased cell-cell contact and local microenvironmental signals. Phys Biol 10: 035003

YASUMI, T., INOUE, M., MARUHASHI, M., KAMACHI, Y., HIGASHI, Y., KONDOH $\mathrm{H}$. and UCHIKAWA, M. (2016). Regulation of trunk neural crest delamination by deltaEF1 and Sip1 in the chicken embryo. Dev Growth Differ 58: 205-214

ZHANG, S., SU, Y., GAO, J., ZHANG, C. and TANAKA, H. (2016). A potential inhibitory function of draxin in regulating mouse trunk neural crest migration. In vitro Cell. Dev. Biol. -Animal 1-11.

ZUHDI, N., ORTEGA, B., GIOVANNONE, D., RA, H., REYES, M., ASENCION, V., MCNICOLL, I., MA, L. and DE BELLARD, M.E. (2015). Slit molecules prevent entrance of trunk neural crest cells in developing gut. Int J Dev Neurosci 41: 8-16. 


\section{Further Related Reading, published previously in the Int. J. Dev. Biol.}

Evolution of the vertebrate claudin gene family: insights from a basal vertebrate, the sea lamprey Christian Mukendi, Nicholas Dean, Rushil Lala, Jeramiah Smith, Marianne E. Bronner and Natalya V. Nikitina Int. J. Dev. Biol. 60: 39 - 51 (2016)

http://dx.doi.org/10.1387/ijdb.150364nn

Bone morphogenetic protein 4 promotes craniofacial neural crest induction from human pluripotent stem cells

Sumiyo Mimura, Mika Suga, Kaori Okada, Masaki Kinehara, Hiroki Nikawa and Miho K. Furue Int. J. Dev. Biol. 60: 21 - 28 (2016) http://dx.doi.org/10.1387/ijdb.160040mk

Two different vestigial like $\mathbf{4}$ genes are differentially expressed during Xenopus laevis development

María-Guadalupe Barrionuevo, Manuel J. Aybar and Celeste Tríbulo

Int. J. Dev. Biol. (2014) 58: 369-377

http://dx.doi.org/10.1387/ijdb.130353ct

The transcriptional coactivators Yap and TAZ are expressed during early Xenopus development

Susumu Nejigane, Yoshikazu Haramoto, Makoto Okuno, Shuji Takahashi and Makoto Asashima.

Int. J. Dev. Biol. 55: 121 - 126 (2011)

http://dx.doi.org/10.1387/ijdb.103130sn

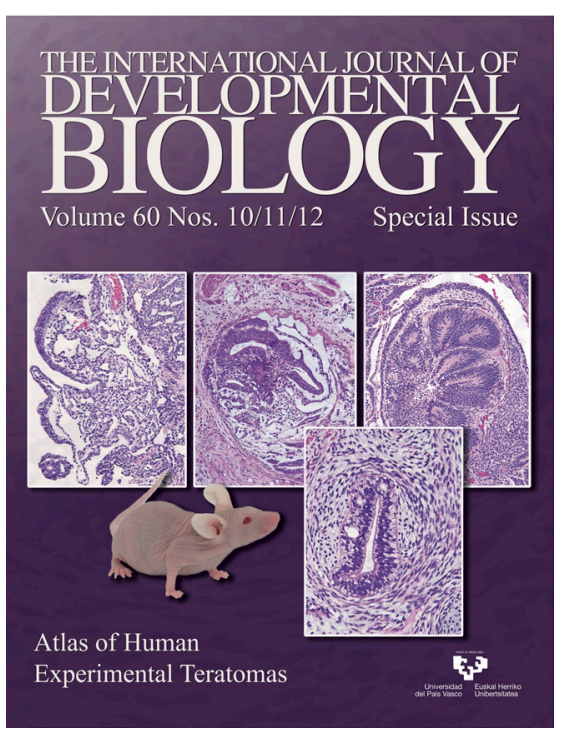

5 yr ISI Impact Factor $(2013)=2.879$

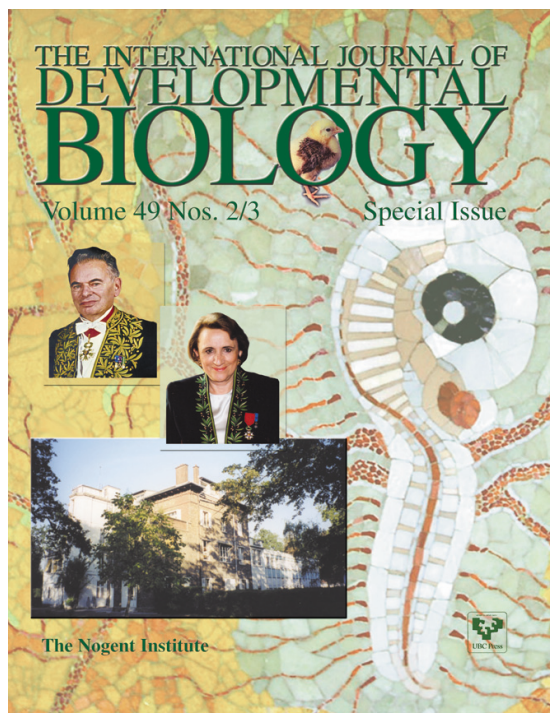

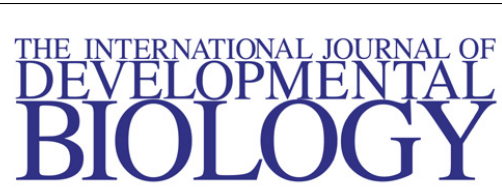

Volume 48 Nos. $5 / 6$

Special issue

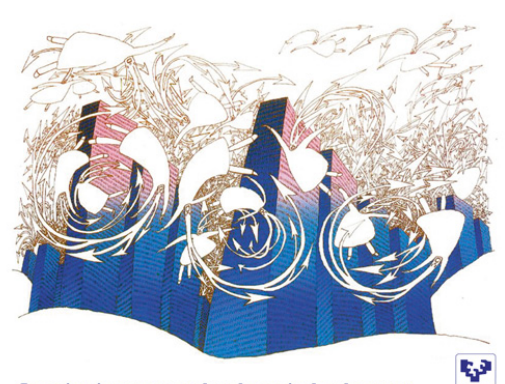

Invasion in cancer and embryonic development

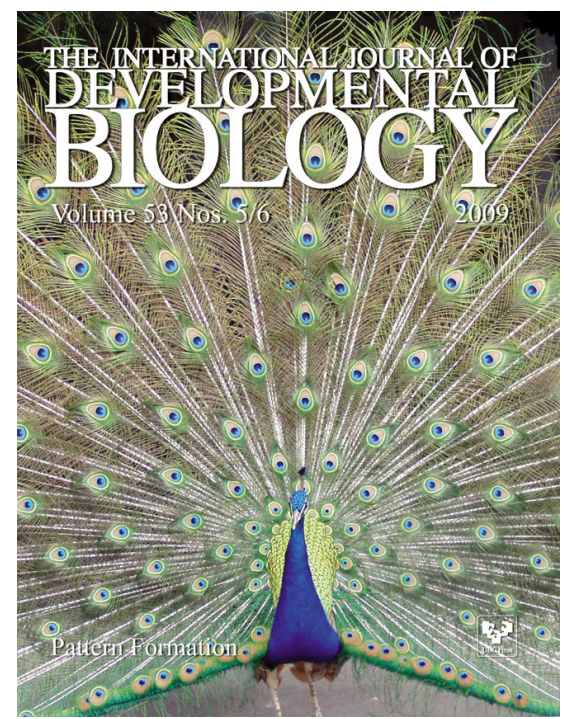

